

\section{Para Paulo Francis, com amor e sordidez: o naufrágio político da geração '60*}

To Paulo Francis, with love and squalor: the political wreck of the 1960s generation

\section{Carlos Eduardo Rebello de Mendonça}

\section{RESUMO}

Este artigo se debruça sobre a carreira do jornalista e ensaísta Paulo Francis (1930-1997) buscando explicar a razão da sua influência e da mudança das suas posições políticas num sentido cada vez mais direitista, como uma história de caso que habilitaria uma investigação sobre o papel e evolução política dos intelectuais de classe média no Brasil e no mundo, de meados para fim do século $X X$ e na passagem da ditadura militar a uma redemocratização de cunho neoliberal.

PALAVRAS-CHAVE: Paulo Francis; história brasileira contemporânea; política brasileira.

\begin{abstract}
This paper investigates the career of the Brazilian journalist-essayist Paulo Francis (1930-1997), the reasons for his influence and for the change in his political stance towards an ever more extreme rightist position. It takes Francis' case-history as a tool allowing discussion on the role and political evolution of middle-class intellectuals in Brazil and worldwide from the mid-20th. Century to the present - and, in the specific Brazilian context, from the military dictatorship towards neoliberal re-democratization.
\end{abstract}

KEYWORDS: Paulo Francis; contemporary Brazilian history; Brazilian politics.

Considerando as circunstâncias, você matou aquele gatinho da maneira mais varonil possivel.

J. D. Salinger. "Para Esmê, com amor e sordidez".

Escrever um festschrift como este é assumir uma dívida intelectual, reconhecer uma influência - escrever em "honra de". E este festschrift, dirigido a uma personagem sobre cuja influência intelectual o autor não pode ter dúvida alguma - não fosse ele quem me apresentou, em finais dos anos 1960, à figura de Trotsky -, não deveria colocar problema algum, não fosse pela lastimável trajetória política e intelectual do homenageado, tão lamentável a ponto de acabar por pôr em dúvida sua qualidade mesma de intelectual... ${ }^{1} \mathrm{Um}$ jornalista pretensioso que virou intelectual de televisão e morreu afogado nas suas próprias secreções reacionárias; o que há aí para ser homenageado?

\footnotetext{
* Artigo concluído no Rio de Janeiro em 25 abr. 2021, dia do 93º aniversário de meu pai, a cuja memória dedico este trabalho. Agradeço as sugestões do parecerista.

${ }^{1}$ Ver LEITE, Ligia Chiappini Moraes, DIMAS, Antônio e ZILLY, Berthold, (orgs.). Brasil, País do passado? São Paulo: Edusp, 2000, p. 20.
} 
Comecemos, portanto, falando do que constitui a qualidade de "intelectual". Há diversos trechos dos Cadernos do cárcere de Gramsci em que o marxista sardo lembra, en passant, que nenhuma produção cultural é ontologicamente "intelectual" no sentido de ser absolutamente "original" ou "universal", e que, portanto, em toda "alta" cultura existe sempre um elemento "folclórico" (local, provinciano), do mesmo modo que na literatura mais popular existe um pouco da "filosofia da época": assim, no Conde de Monte Cristo, nos deparamos com a consciência popular (e pequeno-burguesa) das injustiças sofridas, a serem resolvidas por uma desforra individual. ${ }^{2}$ Ao mesmo tempo, na filosofia nietzscheana, esse ressentimento pequeno-burguês é elevado à dignidade filosófica do "super-homem". ${ }^{3}$ E conclui Gramsci dizendo que se, num Garibaldi, havia muito de herói de folhetim de capa e espada, rasgos pomposos e melodramáticos que tornariam o velho líder do Risorgimento ridículo até na Itália do início do século $X X$, era que tais traços, nesse país novecentista, não seriam ridículos de forma alguma: "em sua época, Garibaldi não era na Itália nem anacrônico nem provinciano, porque toda a Itália era anacrônica e provinciana". ${ }^{4}$

Não existe, pois, um fosso intransponível entre a "alta" cultura e a "cultura popular"; inclusive porque todos, intelectuais profissionais e leigos, participam em certa medida de uma concepção de mundo que deriva da sua inserção automática num grupo social..$^{5}$ Francis, aliás, dizia coisa semelhante de Nelson Rodrigues ao assinalar, como um dos traços mais salientes do teatrólogo pernambucano, a sua sesquipedal ignorância ${ }^{6}$, que se combinava organicamente ao seu anticomunismo visceral: "Nada sabia do assunto [...] detestava o comunismo porque este previa uma sociedade organizada logicamente [sic]. E Nelson odiava a lógica por definição". ${ }^{7}$ Em outras palavras, o grande dramaturgo detestava qualquer modernidade, mesmo que burguesa, com todas as suas forças de pequeno-burguês enfurecido e ignorante; e o culto à sua genialidade, que tanto agastava os intelectuais progressistas contemporâneos - "taradão ilustre", como escreveu Oswald de Andrade ${ }^{8}$ - talvez fosse, mais do que a expressão de uma carência, dos "abismos da nossa incultura" a expressão da cultura própria de um determinado momento histórico: o culto a si mesmo de um Brasil pequeno-burguês, enfurecido e ignorante, ao qual nem sequer os intelectuais "superiores" puderam escapar em alguma medida.

O mau gosto e o melodramático não seriam, assim, em tais casos, efeitos de uma insuficiência intelectual objetiva, mas sim de exigências da situação histórica: "como certos países permaneceram provincianos e atrasados [...]

\footnotetext{
${ }^{2}$ Cf. GRAMSCI, Antonio. Cadernos do cárcere, v. 6. Rio de Janeiro: Civilização Brasileira, 2002, p. 169.

${ }^{3}$ Idem, ibidem, p. 231.

${ }^{4}$ Idem, ibidem, p. 232.

${ }^{5}$ Cf. GRAMSCI, Antonio, op. cit., v. 1, p. 93 e 94.

6 "É uma das pessoas mais ignorantes que conheço. Só lê jornais e, assim mesmo, com ênfase nas seções de polícia e esportes [...] sua ignorância é justificada, em parte, por um supersticioso senso de defesa de sua personalidade". FRANCIS, Paulo. Opinião pessoal. Rio de Janeiro: Civilização Brasileira, 1966, p. 171).

${ }_{7}^{7}$ Obituário de Nelson Rodrigues, publicado originalmente em 28 dez. 1980. FRANCIS, Paulo. Diário da Corte. São Paulo: Três Estrelas, 2012, p. 130.

${ }^{8}$ ANDRADE, Oswald de. O analfabeto coroado de louros. Correio da Manhã, Rio de Janeiro, 8 jun. 1952. Disponível em <http://prosacaotica.blogspot.com/2008/07/picuinhas-literrias-oswald-de-andrade-x.html . Acesso em 31 dez. 2020.

${ }_{9}^{9}$ Idem.
} 
em alguns países ainda se está em Monte Cristo e Fenimore Cooper". ${ }^{12} \mathrm{E}$ tal reação pequeno-burguesa à estreiteza do meio social poderia manifestar-se de várias maneiras, diz Gramsci: no gosto da política entendida como conspiração e intriga - mas também num elitismo pseudo-aristocrático de imitação, cujo representante por excelência em Gramsci era Curzio Malaparte, cujas características mais salientes eram o "arrivismo desenfreado, uma desmedida vaidade e um esnobismo camaleônico: para ter sucesso [...] era capaz de qualquer perfídia"13. Na periferia do capitalismo imperialista, tal esnobismo terá como uma das suas formas mais comuns "o sentimento [...] de perda de encanto pela pátria, a sensação de que 'o Brasil já era'". ${ }^{14}$

Gramsci acrescenta, no caso, que este último estado de espírito, a recusa da própria cultura e do povo, seria precisamente um sintoma da doença que supostamente quer combater: "além de ser uma estupidez, é um índice importante da ausência de espírito nacional-popular". ${ }^{15} \mathrm{O}$ intelectual pequeno-burguês enfastiado censura no "povo" a sua dependência da classe dominante: "em vez de admitirem sua própria incapacidade orgânica, consideram mais cômodo admitir que todo um povo é inferior, pelo que nada mais resta a fazer senão acomodar-se". ${ }^{16}$ "No meu fim está o meu começo" - citação de um dos Quatro quartetos, de T. S. Eliot, que pertencia ao estoque de citações recorrentes de Francis, e que termina propondo que a agitação do mundo se resolva na quietude metafísica (The only wisdom we can hope to acquirel Is the wisdom of humility). ${ }^{17} \mathrm{~A}$ revolta moralizante do intelectual insatisfeito aponta desde sempre para sua reconciliação final com a ordem estabelecida. O angry young man contém em germe o moralizante reacionário que verbera a humanidade pecadora - "um cachorrinho ferido que fica lambendo eternamente a própria ferida". ${ }^{18}$

Que os praticantes de tais lamentações moralizantes e outras semelhantes não sejam considerados "dignos" do nome de intelectuais é algo que decorre - como sumariza Gramsci na sequência dum trecho famoso dos Cadernos ("todos os homens são filósofos") - do erro que consiste em supor que o intelectual seja necessariamente a consciência crítica do seu tempo, o guia de si mesmo; muito pelo contrário, é mais comum que ele dê uma forma mais expressiva a uma concepção de mundo já existente no seu grupo social. ${ }^{19}$ Noutro trecho, já citado, dos mesmos Cadernos, Gramsci chega a perguntar-se se Nietzsche não teria sido "de algum modo influenciado pelos romances de folhetim franceses", na medida em que o intelectual pequeno-burguês, numa sociedade atrasada, tenderia a ser irresistivelmente atraído "por tais imagens romanescas, que são seu 'ópio', seu 'paraíso artificial', em contraste com a mesquinhez e a estreiteza de sua vida real imediata [...] 'é melhor viver um dia

\footnotetext{
${ }^{12}$ GRAMSCI, Antonio, op. cit., v. 4, p. 57.

${ }^{13}$ Idem, ibidem, v. 6, p. 81.

${ }^{14}$ KUCINSKI, Bernardo. A síndrome da antena parabólica. São Paulo: Perseu Abramo, 1998, p. 87.

${ }^{15}$ GRAMSCI, Antonio, op. cit., v. 6, p. 81.

${ }^{16}$ Idem, ibidem, p. 82.

${ }_{17}$ ELIOT, T. S. Four quartets. Disponível em <http://philoctetes.org/documents/Eliot\%20Poems.pdf >. Acesso em 29 dez. 2020

${ }^{18}$ FRANCIS, Paulo. Diário da Corte, op. cit., p. 131.

${ }^{19}$ Concepção de mundo "que pode ser a própria aldeia ou a província, pode se originar na paróquia e na 'atividade intelectual' do vigário [...] na mulher que herdou a sabedoria das bruxas, ou no pequeno intelectual avinagrado". GRAMSCI, Antonio, op. cit., v. 1, p. 94.
} 
como leão do que cem anos como ovelha' [é um dito de] sucesso particularmente intenso junto a quem é precisa e irremediavelmente uma ovelha" ${ }^{20}$ Como no caso, por exemplo, de um jornalista de pretensões intelectuais infladas gastando-se no ramerrão de uma redação de jornal num país periférico.

Trotsky, aliás, num ensaio de juventude sobre Nietzsche, não escreveu nada muito diverso de Gramsci quando disse que o nietzscheanismo era de certa forma "apenas" a ideologia de um parasitenproletariat composto por "aventureiros das finanças, super-homens da Bolsa, chantagistas inescrupulosos da política e do jornalismo [...] toda uma massa de proletários parasitários [...] que, de uma forma ou outra, não vivem tão mal assim às custas da sociedade sem dar-lhe nada em troca" 21 ; aqueles que rejeitam a superestrutura da moral burguesa convencional, mas nunca sua base econômica. Finalmente, seria um outro autor marxista (muito utilizado por Paulo Francis), Isaac Deutscher, que diria que a marca dos intelectuais originais está na ausência relativa de impacto imediato: “Uma obra de grande mérito literário é usualmente complexa demais na sua textura e demasiadamente sutil em pensamento e forma para prestar-se à exploração $a d h^{\prime \prime}$; inversamente, os intelectuais "secundários" estarão muito mais apetrechados para responderem de maneira imediata a uma "demanda social" por um efeito de "atordoamento" 22 (o que nem sempre será uma tarefa prejudicial ou reacionária).

\section{Francis no seu tempo: Goulart e a revolução brasileira}

Tanto como a obra dramatúrgica do seu duplo Nelson Rodrigues ("a flor da obsessão"), a obra intelectual de Francis - seus ensaios e crônicas - não evoluiu quanto ao seu conteúdo e forma: num texto da década de 1990, encontram-se os mesmos tropos, bon mots e citações recorrentes dos anos 1950 e 1960, talvez apenas acrescidos de um coloquialismo dos tempos d'O Pasquim, que foi se tornando numa chulice cada vez mais sórdida, avidamente copiada pelos seus epígonos tardios de direita. Isto dito, por que não ir direto à fonte? No caso, a coletânea de ensaios que Francis publicou logo após o golpe de 1964, Opinião pessoal, num momento em que ainda prevalecia uma frente única informal das esquerdas para a resistência à ditadura, numa conjuntura que estimulava, de certo modo, a redação de sínteses intelectuais e busca de denominadores comuns; e daí viria a peça que abre a coletânea, “Tempos de Goulart". Superficial que possa hoje parecer - mas até que ponto essa "superficialidade" não seria apenas o pensamento da época? -, trata-se de uma tentativa de reflexão sobre o tema da liderança política daquilo que um Nelson Werneck Sodré chamaria "a Revolução Brasileira".

Surpreendentemente para quem lê em 2020 esse artigo escrito em 1966, é impressionante o quanto o seu autor - com todas as suas carências evidentes de conhecimento teórico e de ideias gerais - consegue realizar uma apreciação do seu passado recente e da situação presente de forma fundamentalmente justa. A contrapelo do que se tornou uma interpretação revisionista corrente -

\footnotetext{
${ }^{20}$ Idem, ibidem, v. 4, p. 55 e 57.

${ }^{21}$ TROTSKY, Leon. On the philosophy of the superman [1900]. Disponivel em <https://www.marxists.org/ archive/trotsky/1900/12/nietzsche.htm>. Acesso em 29 dez. 2020.

${ }^{22}$ DEUTSCHER, Isaac. Heretics \& renegades. Londres: Hamish Hamilton, 1955, p. 36 e 35.
} 
a de que o golpe de 1964 decorreu da rejeição, pela esquerda, do reformismo produtivo dentro do quadro institucional vigente e de uma opção pelo radicalismo insurrecional ${ }^{23}$-, o que Francis começa lembrando é que a coalizão reformista tinha padecido da extrema timidez da cúpula; Goulart tinha sido precisamente, durante toda a sua carreira política, o herdeiro de Vargas, um político de conchavos e acordos, do dar tempo ao tempo, e que mesmo a acusação do seu "despreparo" para propor uma agenda negociada caía falsa bastaria pensar na simples comparação entre um Celso Furtado e Evandro Lins e Silva com as "sumidades" do primeiro governo da ditadura... Inclusive - acrescentava Francis - porque liderança política não é simplesmente cultura formal - "ou Trotsky, e não Stalin, teria tomado o poder depois de Lênin" -, e sim "o senso de oportunidades de ação, dos meios de aproveitá-la e a energia para esgotá-las".

Por mais intuitiva que seja, trata-se de uma definição impecavelmente maquiavélica da política como virtú, e da situação revolucionária como imposição "manobrada" de uma resolução das contradições acumuladas - o que Francis reitera quando lembra o passado imediato: “Eu próprio, em vários artigos para o Última Hora, instiguei [Goulart] a valer-se do poder na plenitude, a livrar-se da quinta-coluna em todo o organismo executivo, o que acabou sendo feito pelos usurpadores do $1^{\circ}$ de Abril [...] Mas o Presidente recusou-se a governar" ${ }^{24} \mathrm{O}$ poder é - conforme Michel Foucault -, antes de qualquer coisa, algo que se exerce.

De maneira titubeante e intuitiva, o articulista vai desenvolvendo seus argumentos: naquele Brasil dos anos 1960, o consenso reacionário teria duas faces: uma, manifestamente reacionária, a do moralismo burocrático: "honestidade e eficiência" - que correspondem ao common sense pequeno-burguês, de quem vê na política uma "extensão de suas batalhas com as empregadas, varejistas de mantimentos, etc." ${ }^{25}$-, a expressão do grande patrimônio nacional de ignorância.... Mas a sua segunda cara, não menos reacionária, seria a do "populismo", das ideias mínimas reformistas: "anti-imperialismo", "reforma agrária" - todas estas posições sendo perfeitamente compatíveis, de partida, com a institucionalidade burguesa, e que Francis compara, grotescamente (porém de forma bastante significativa) "com "o 'quadro sério' no teatrorevista da Praça Tiradentes [carioca], onde, para quebrar a rotina de pornografia, representava-se uma exaltação à Pátria e suburbanices [sic] congêneres. Era um acréscimo dispensável ao espetáculo, mas presumivelmente apaziguava a consciência dos empresários “. ${ }^{26}$

Esta tirada é importante, precisamente pelo seu caráter emblemático: ela expressa e ressalta um ponto forte de Francis - a sua capacidade de estabelecer uma ligação direta entre a "conversa de botequim" e o debate culto. Esse jornalista, que seus próprios contemporâneos já caracterizavam como "chutador" e portador de uma cultura de almanaque adquirida em leituras de ore-

\footnotetext{
${ }_{23}$ "Os grupos esquerdistas [...] para obter as reformas, propunham e estavam dispostos a apoiar soluções não democráticas". FIGUEIREDO, Angelina Cheibub. Democracia ou reformas? São Paulo: Paz e Terra, 1993, p. 202.

${ }^{24}$ FRANCIS, Paulo. Opinião pessoal, op. cit., p. 16 e 17.

${ }^{25}$ Idem, ibidem, p. 16.

${ }^{26}$ Idem, ibidem, p.19.
} 
lhas de livro ("pula de um livro para outro como uma gazela", teria dito - et pour cause - o seu alvo e duplo Nelson Rodrigues ${ }^{27}$ ), tinha por vezes o talento de resumir, com uma única expressão feliz, o que normalmente exigiria todo um texto acadêmico - como o de Roberto Schwarz, escrito na década de 1970, em que o autor, ao final de várias páginas, chega a conclusões praticamente idênticas às de Francis: o programa das esquerdas brasileiras dos anos 1960 resumia-se a "uma problemática explosiva mas burguesa de modernização e democratização [que] no plano ideológico resultava [n]uma noção de 'povo' apologética e sentimental".$^{29}$

Como lembra Francis no seu texto, tal reformismo filantrópico e sem contornos de classe poderia perpetuar-se indefinidamente - contanto que seus sujeitos permanecessem, sempre, no campo das elites tradicionais; porque, "quando a esquerda perde a cabeça e se julga no poder, ou participante dele, como nos últimos tempos de Jango" - (e Francis certamente estava pensando no CGT, o Comando Geral dos Trabalhadores, nas ligas camponesas e no movimento dos sargentos) -, "o populismo se alinha com a mais negra reação para defender o estado de coisas, pois é um dos seus sócios proprietários" ${ }^{30} \mathrm{E}$ Francis destaca que o espectro invocado pelas direitas da época - e apropriado tel quel pelo revisionismo histórico subsequente - da possibilidade de Goulart decretar o estado de sítio em 1963 contra Lacerda e Arraes e impor uma ditadura nacionalista de base militar era, de saída, irrealizável, pois "lhe seria insuportável conviver com uma esquerda estrutural e ideológica, que ameaçasse apagar as aspas do processo revolucionário [...] se arriscaria a perder o controle do movimento popular, se este se organizasse e diversificasse". ${ }^{31}$

\section{A questão da liderança revolucionária}

Em outras palavras, Francis claramente chegou a dominar os fundamentos da aplicação da teoria da revolução permanente de Trotsky à conjuntura brasileira dos anos 1960, ao considerar que as tarefas propriamente liberal-burguesas da revolução brasileira exigiriam objetivamente meios mais radicais do que o simples reformismo:

as esquerdas viveram de certa maneira o dilema menchevique/bolchevique de 1917 [na verdade, mais o dilema no interior do próprio bolchevismo a partir do enunciado das Teses de abril por Lênin]: apoiariam um movimento burguês antiimperialista, que concretizasse as promessas da Revolução de 1930 [supondo o caráter "liberal" desta...], ou executariam um salto dialético, passando do desenvolvimento semicolonial a uma tentativa de república popular [sic]?32

Até aí, tudo bem - não fora o fato de que, a tal diagnóstico da situação brasileira pré-1964, segue-se uma descrição resumida e idiossincrática da Revolução Russa: "Sabemos que a Revolução soviética foi um golpe de estado

\footnotetext{
${ }^{27}$ Cf. BELÉM, Euler de França. O centenário de Nelson Rodrigues. Revista Bula, 28 abr. 2012. Disponível em $<$ https://acervo.revistabula.com/posts/colunistas/o-centenario-de-nelson-rodrigues $>$. Acesso em 23 jan. 2021.

${ }^{29}$ SCHWARZ, Roberto. Cultura e política. São Paulo: Paz e Terra, 2001, p. 13.

${ }^{30}$ FRANCIS, Paulo. Opinião pessoal, op. cit., p. 19.

${ }^{31}$ Idem, ibidem, p. 20

32 Idem, ibidem, p. 21.
} 
minuciosamente planejado e executado, onde [sic] uma minoria capitalizou o descontentamento popular e, já no poder, deu-lhe configuração socialista". ${ }^{33}$

Como descrição, nada há de errado no parágrafo acima: a Revolução de Outubro foi um golpe de mão, um evento pontual intencionalmente planejado, preparado e executado por um grupo reduzido de pessoas. Como análise de um processo histórico, no entanto, a descrição é claramente insuficiente, e adoece do igualmente claro elitismo - à maneira de Dumas/Nietzsche - do narrador.

Há um escrito aparentemente menor de Trotsky em que ele discute tal problema do papel da liderança revolucionária, polemizando, em fins da década de 1920, com um Winston Churchill que ainda não tinha chegado a primeiro-ministro, mas que já era uma das vozes autorizadas do conservadorismo britânico e ministro das Finanças. Churchill escrevera uma história do mundo do pós-“Grande Guerra" na qual Lênin e a Revolução Russa eram, obviamente, atacados nos termos mais vitriólicos; quanto à revolução como processo, o conservador inglês contentava-se com uma explicação simples e conspiratória: ela pôde desencadear toda sua força destrutiva a partir do momento em que, após a Revolução de Fevereiro, a prática de bater continência aos oficiais foi proibida (explicação que é preservada, somente com mais detalhes tópicos, na história da revolução do americano ultrarreacionário Richard Pipes). Trotsky replica:

Este era o ponto de vista dos velhos generais descontentes e dos jovens subalternos ambiciosos; no mais, é simplesmente absurdo. O velho exército representava a supremacia das velhas classes dominantes e foi destruído pela revolução. Quando os camponeses tomam as terras dos latifundiários, é difícil imaginar que seus filhos possam continuar a servir sob as ordens de oficiais que são filhos de latifundiários. $O$ exército não é uma organização puramente técnica preocupada apenas com paradas e promoções, mas uma organização moral, que se funda sobre um esquema definido de relações entre classes e indivíduos. Se tal esquema é desbaratado por uma revolução, o exército entra inevitavelmente em colapso. Sempre foi assim... ${ }^{34}$

O que Trotsky está dizendo é que, na origem da Revolução Russa, estava a disposição espontânea e generalizada das massas populares de desbaratarem as relações de classe existentes na sua generalidade - e com elas, os seus penduricalhos morais, políticos e ideológicos. Os "de baixo" simplesmente não queriam mais ser governados como vinham sendo ${ }^{35}$, e o que os bolcheviques fizeram foi dar uma forma política definida a um tsunami elementar. $\mathrm{E}$ é exatamente nesse ponto, ao não reconhecer a existência de uma base espontânea, do movimento "de baixo para cima" sobre o qual a Revolução Russa desenvolveu-se, que Francis começa a tresler a revolução brasileira e seu caráter: como seu análogo italiano, Malaparte, ele vê na revolução apenas uma

\footnotetext{
${ }^{33}$ Idem.

${ }^{34}$ TROTSKY, Leon. Churchill as biographer and historian. In: Art and revolution. New York: Pathfinder, 1992, p. 168.

${ }^{35}$ Condição necessária - mas não suficiente - de qualquer situação revolucionária, cf. LÊNIN, V. I. The collapse of the Second International. Disponível em <https://www.marxists.org/archive/lenin/works/1915/ csi/ii.htm>. Acesso em 1 jan. 2021.
} 
"técnica do golpe de estado". Ele não vê o que Trotsky chamava o desejo das massas de "falar alto", заговорить вслух. ${ }^{36}$

Sempre que mencionado nas histórias da época, Francis é descrito como brizolista radical e aficionado dos Grupos de Onze. É interessante, no entanto, que, olhando para trás em 1966, ele faça questão de desautorizar retrospectivamente a tentativa de golpe de mão do caudilho, em fins de 1963, para apoderar-se da agenda pública do governo do cunhado, que empossaria Brizola no ministério da Fazenda. ${ }^{37}$ Mais interessante ainda é o fato de que Francis fizesse questão de declarar-se retrospectivamente, em plena ditadura, como um entusiasta da permanência de banqueiro Carvalho Pinto no dito ministério, o que para ele viabilizaria a agenda da "revolução brasileira" nos termos mesmo de um Werneck Sodré e do PCB (revolução "antifeudal e antiimperialista"): "o progresso viria de cima para baixo, sob o comando das forças empresariais brasileiras, amparadas nos pacientes [sic] trabalhadores. $\mathrm{O}$ imperialismo americano seria derrotado [sic] pela frente única do capital e trabalho nativos". ${ }^{38}$ Que a política econômica do político e banqueiro paulista fosse apenas uma continuação da política de austeridade fiscal do Plano Trienal de Celso Furtado \& Santiago Dantas, que não apontava para qualquer possibilidade de mudança estrutural ou de investimento público, fora uma vaga "expansão seletiva do crédito" 39 -, isso não é sequer mencionado.

E nem poderia ser diverso, aliás: romper com a camisa de força da austeridade fiscal, naquele momento - fosse tal ruptura viável ou não - seria oferecer capacidade de pressão extra aos movimentos sociais reformistas, deixálos com as mãos livres, coisa que a "burguesia nacional" jamais admitiria. É óbvio que Francis era completamente ignorante em Economia - mas também o era Brizola, que se mostrou perfeitamente capaz de entender o objetivo político da sua manobra, como lembra Neiva Moreira: “Naquele tempo, o Ministério da Fazenda exercia uma função política reitora. Então, o Brizola achava que, indo para o Ministério da Fazenda, ele poderia mudar completamente a linha política do governo. [...] Eram essas as nossas preocupações: fazer as reformas, conseguir recursos para executá-las". ${ }^{40}$

Só que, para Francis, Carvalho Pinto é que seria o homem certo no lugar certo, já que se tratava de um burocrata fundamentalmente correto, capaz de barrar a porta do ministério às negociatas e oferecer uma base fiscal sólida aos projetos reformistas: "Carvalho Pinto reduziu as verbas da oligarquia po-

\footnotetext{
36 Trotsky, Leon. ИСТОРИЯ РУССКОЙ РЕВОЯЮЦИИ - ТОМ ВТОРОЙ ОКТЯБРЬСКАЯ РЕВОЛЮЦИЯ. Disponível em <https:/www.marxists.org/russkij/trotsky/works/ trotl009.html>. Acesso 31 dez. 2020.

37 Cf. Dicionário biográfico do CPDoc. Verbete Leonel de Moura Brizola. Disponível em $<$ http://www.fgv.br/cpdoc/acervo/dicionarios/verbete-biografico/leonel-de-moura-brizola>. Acesso 30 dez. 2020.

${ }^{38}$ FRANCIS, Paulo. Opinião pessoal, op. cit., p. 24 e 25.

${ }^{39}$ BATISTA, Felipe Ferreira e CARVALHO, Carlos Eduardo. Carvalho Pinto: três aspectos de um destacado político paulista do século XX. Anais do XIII Congresso Brasileiro de História Econômica. Criciúma, set. 2019. Disponível em <http://www.abphe.org.br/arquivos/2019-felipe-ferreira-batista--carlos-eduardo-carvalho. pdf>. Acesso em 30 dez. 2020.

${ }^{40}$ Cf. ROLIM, César Daniel de Assis. A formação da Frente de Mobilização Popular e a organização do povo contra o antipovo nos pronunciamentos políticos de Leonel Brizola (1963-1964). Anais do XXIII Simpósio Nacional de História. Florianópolis, jul. 2015. Disponível em <http://www.snh2015.anpuh.org/resources/ anais/39/1434420931_ARQUIVO_CesarDanieldeAssisRolim.pdf>. Acesso em 30 dez. 2020.
} 
pulista, que o empregara. Revelou-se, portanto, um 'subversivo' do único tipo não tolerado no Governo Goulart". ${ }^{41}$

Tal pressuposto - o de que reformas econômicas consequentes só pudessem vir a ser realizadas por um homem do "mercado", ou seja, um burocrata da iniciativa privada - dá conta dos limites do "radicalismo" de Francis. Reformas de base, sim, radicalismo sim, mas "de acordo com o regulamento" - isto é, com respeito às exigências instrumentais objetivas, aplicadas imparcialmente por gestores qualificados. O problema é que a gestão burocrática está subordinada à organização política geral da sociedade, e se esta sofre uma transformação revolucionária, a desorganização da burocracia é inevitável. Que Francis não percebesse tal coisa explicita a causa principal da sua subsequente derrota reacionária - e de tantos outros membros da "geração 60" brasileira: o seu elitismo fundamental.

Como recorda Isaac Deutscher num artigo sobre o diplomatahistoriador britânico E. H. Carr, a Revolução Russa, especialmente a partir dos anos 1920, proveu-se de uma série de simpatizantes conservadores - como o próprio Carr -, intelectuais da burguesia educada que viam com admiração a capacidade dos bolcheviques, após o "comunismo de guerra", de reconstruírem um aparelho de Estado não apenas funcional como eficiente. Como assinala Deutscher, a "simpatia" de Carr por Lênin era extremamente qualificada e condicional:

Aplica-se a Lênin como estadista e mestre autodidata da arte de governar, em distinção ao pensador e revolucionário marxista. É o Lênin que constrói um Estado que evoca sua admiração, não o que derruba um Estado, e menos ainda o que obstinadamente sonha com o "deperecimento" gradual deste Estado que é sua obra [...] Ele se deixa impressionar por aquilo que Lênin pudesse ter tido em comum com - digamos Bismarck, e não por aquilo que demonstre sua afinidade com Marx, os communards, ou Rosa Luxemburgo. ${ }^{42}$

E nem precisaríamos sair do Brasil, em termos de exemplos em apoio de uma posição semelhante: o Lênin exaltado calorosamente pelo católico integrista e filofascista Octavio de Faria no seu Destino do socialismo é o Lênin de 1920 e da NEP (Nova Política Econômica), em oposição ao de 1917 e da Revolução de Outubro. Tal atitude política, pré-Guerra Fria, era tão comum a ponto de receber um nome: o "nacional-bolchevismo". Tratava-se - sobre o pano de fundo da depressão capitalista endêmica do período do entreguerras - de desejar emular os êxitos econômicos soviéticos (urbanização, industrialização, alfabetização, os planos qüinquenais), rejeitando a sua base social (a ditadura do proletariado).

Trotsky, como Francis o via, era a representação de uma atitude e de uma visão de mundo similares: é o Trotsky comissário da guerra e grande orador - mas jamais o militante revolucionário fazendo trabalho de base juntamente com as massas. Na verdade, é o Trotsky dos intelectuais de esquerda americanos antistalinistas da Partisan Review nova-iorquina, com os quais cer-

\footnotetext{
${ }^{41}$ FRANCIS, Paulo. Opinião pessoal, op. cit., p. 25.

${ }^{42}$ DEUTSCHER, Isaac. E. H. Carr e as historian of the Bolshevik Régime. In: Heretics \& renegades, op. cit., p. 97 e 98.
} 
tamente Francis entrou em contato durante sua pós-graduação (incompleta) sob a supervisão do crítico, dramaturgo e tradutor de Brecht para o inglês Eric Bentley, na Universidade de Columbia: uma figura monumental, mas, ao mesmo tempo, alienígena.

Note-se que, na época de Francis, o "nacional-bolchevismo", diante da prosperidade econômica do mundo capitalista do pós-guerra e do declínio do regime stalinista, tinha cessado de ser uma postura política válida -, mas não as simpatias por um esquerdismo sem afiliação de classe, só que agora de tonalidade politicamente libertária. Daí a face idealizada dos anos 1960, como passaram a ser recordados desde a época de Margaret Thatcher: como uma espécie de paraíso perdido em que floresciam a liberação de costumes, a secularização da sociedade, a abertura a todo tipo de experimentos políticos; alguma coisa como a fórmula ad hoc "Maio 68 + Woodstock". O que essa idealização não deixa perceber é que a cultura soixante-huitarde era basicamente elitista - cultivada basicamente por uma pequeno-burguesia emergente gozando do seu veranico político-social ${ }^{43}$ antes do longo inverno da sua proletarização/precarização - e politicamente frágil: a história de maio de 1968 é a história do seu fracasso em sequer começar a abalar a hegemonia do PCF sobre a massa proletária. E que o Maio francês tenha durante muito tempo desembocado na exaltação deslocada a uma representação mais que idealizada do maoísmo da Revolução Cultural dá bem conta do seu caráter mais do que autoritário, apolítico: a crença nas ilusões redentoras de preferência à política real. ${ }^{44}$ Um dos membros do gabinete de Thatcher comparava a década de 1960 a uma "residência assistida" de idosos [sunset home] ${ }^{45}$; e, de certa forma, tinha razão: a crença nos belos ideais adquiria uma qualidade ilusória, de miragem, com qualidades quase de demência, que encobria a realidade da luta de classes sans frase e escondia, principalmente, a convicção burguesa absoluta do seu direito de continuar governando.

O que tinham em comum esses empreendimentos políticos fracassados? Um desejo de realizar algumas tarefas históricas bastante concretas - a modernização econômica, a democratização política radical - que incumbiriam objetivamente, sob o capitalismo, a certas classes determinadas - a burguesia ou o proletariado -, porém sob a liderança político-intelectual de uma seção de outra classe: a pequeno-burguesia educada. O que não é impossível, desde que respeitados os limites das realidades sociais objetivas: o sujeito histórico concreto de qualquer transformação social radical sob o capitalismo é, em última instância, o proletariado - e não, como lembra Trotsky, a ideia democrática "pura" (чистой демократи). ${ }^{46}$

\footnotetext{
${ }^{43}$ Uma das crônicas de Francis, da década de 1980, fala das suas viagens em 1968 e faz uma descrição do chienlit parisiense: "Para aproximar a cena dos meus leitores [...] devo dizer que parecia aquela superiluminação dos filmes de Spielberg, e se cantava, gritava, dançava sem parar". Se non è vero, è molto ben trovato... FRANCIS, Paulo. Diário da Corte, op. cit., p. 284.

44 “Acreditou-se que na China maoísta os homens e as coisas não tinham a mesma banalidade quotidiana que entre nós. Infelizmente, tomou-se esta verdade feérica por um programa político de verdade". VEYNE, Paul. Les grecs ont-ils cru à leur mythes? Paris: Seuil, 1983, p. 33.

${ }^{45}$ CLARKE, Peter. Hope and glory: Britain 1900-2000. Penguin Books, 2004, p. 379.

${ }^{46} \mathrm{O}$ adjetivo em russo passa subsidiariamente - como em português - a ideia de "limpeza", no sentido de "pureza moral". Trotsky, Leon. ИСТОРИЯ РУССКОЙ РЕВОЛЮЦИИ - ТОМ ПЕРВЫЙ-ФЕВРАЛЬСКАЯ РЕВОЯЮЦИЯ. Disponível em <https://www.marxists.org/russkij/trotsky/works/trotl007.html>. Acesso em 23 jan. 2021.
} 
Nas condições brasileiras, entretanto, o elitismo subjacente aos ideais dos anos 1960 só poderia ficar ainda mais marcado. "A imaginação no poder" - mas a imaginação de uma minoria, porque, no mais, valia e vale a pergunta retórica - e furiosa - do protagonista do filme de Glauber Rocha, Terra em Transe: já imaginaram "essa gente" no poder?

Não se trata aqui de justificar Paulo Francis, mas de explicar a sua geração e sua época. Como intelectual público, Francis podia ser uma mistura excessivamente indigesta de pretensão, elitismo pequeno-burguês fake e esnobismo; contudo, sua trajetória nada teve de particularmente único, de irredutivelmente pessoal. Kucinski propõe como termo de comparação a tríade Francis-Geraldo Vandré-Glauber Rocha: “todos abandonaram o Brasil nos anos 70, e todos sofreram um processo de descolamento intelectual, de perda de referências que os levou a graus variados de excitação mental". ${ }^{47}$ Mas ele poderia propor uma lista que se expandiria quase indefinidamente, de intelectuais pequeno-burgueses, de posição progressista e que conseguiram algum grau de proeminência na resistência à ditadura - seja na resistência intelectual, na política parlamentar ou na luta armada -, que, precisamente sob a redemocratização, foram assumindo posições cada vez mais descoladas do seu passado, e sempre no sentido de serem cada vez mais abertamente reacionárias. Há uma causa genérica aqui, portanto; mais do que uma psicologia individual, temos uma política.

\section{O sujeito do processo histórico}

Em 1908, quando Tolstoi comemorava o seu octogésimo aniversário, Trotsky, exilado em Viena, escreveu um comentário sobre a efeméride em que começava dizendo que o grande escritor, que já estava entrado nos trinta quando da abolição da servidão, como descendente das "gerações intocadas pelo trabalho", inevitavelmente tinha "amadurecido e tomado forma na atmosfera da velha nobreza, entre propriedades herdadas, numa casa senhorial espaçosa, à sombra de alamedas de tílias". Assim, por mais que ele tivesse chegado à velhice como um anarquista cristão, "na sua última obra maior, Ressurreição, ele ainda coloca no centro da sua atenção artística o mesmo proprietário aristocrático rico, em torno ao qual está colocada a mesma teia dourada de conexões, hábitos e recordações aristocráticas". Daí que o populismo de Tolstoi não contradizia o seu aristocratismo, antes o reforçava, pois "da mansão do proprietário, uma trilha estreita e direta leva à cabana do camponês. Tolstoi, o poeta, fez este caminho muitas vezes [...] antes que Tolstoi, o moralista, o transformasse no caminho da salvação. Mesmo depois da abolição da servidão, ele continuou a considerar os camponeses como coisa 'sua' - parte inalienável do seu inventário material e espiritual" ${ }^{48}$

O que temos aqui é uma situação comum a toda a periferia do capitalismo: no Brasil de 1964, como na Rússia de 1908, a modernidade é uma planta de estufa, uma ideia fora do lugar, diz Schwarz..$^{49} \mathrm{E}$ nesta periferia, mesmo para os mais "modernos" dos "modernos", a modernidade é algo, em princí-

\footnotetext{
${ }^{47}$ KUCINSKI, Bernardo, op. cit., p. 89.

48 TROTSKY, Leon. Tolstoy: poet and rebel. In: Art and revolution, op. cit., p. 128 e 129.

${ }^{49}$ SCHWARZ, Roberto, op. cit., p. 59, 83, passim.
} 
pio, só aceitável na forma que Tolstoi lhe deu em Iasnaia Poliana, onde o velho escritor e aristocrata vivia cercado de instrumentos de trabalho manual, foice e machado - no salão central da sua mansão ancestral. Aconteça o que acontecer, o sujeito e centro do processo modernizador são sempre as elites, reais ou supostas como tais, já que, sob o verniz da modernidade arranhado, se oculta o "odor a Dostoievsky" dos mujiques bêbados falando alto demais ou de Lula e comitiva.

\section{O ontem e o hoje da história do Brasil}

O teste de ácido da esquerda dos anos 1960 seria exatamente a emergência do PT, por tudo aquilo que tinha de inesperado, de não conscientemente preparado; ela se deu toda no período final da ditadura, a partir do "em si" das classes populares e das suas lutas elementares. Um "em si" que, ao trazer consigo a mera possibilidade do "para-si" já era suficiente para retirar dos esquerdistas pequeno-burgueses o seu protagonismo, o seu inventário. Subitamente, por assim dizer, passou-se da filosofia clássica alemã a Marx: o processo histórico deixou de ser a expressão da modernidade como ideal, da razão universal, para converter-se em expressão do conflito social real. Diante desse teste, a imensa maioria dos esquerdistas dos anos 1960 - que pretendiam recomeçar o jogo exatamente na mesma posição em que estavam em 1964/68 - seria reprovada. E Francis mais do que todos; nos seus escritos a partir de 1988, como diz Kucinski, ele só se referia ao PT em termos tão abjetamente pornográficos a ponto de interditar qualquer reprodução num escrito sério. ${ }^{50}$

Nada objetivamente exigia de Francis esse comportamento desequilibrado (ele já era há muito um jornalista bastante valorizado profissionalmente, alguém que podia escolher a cada momento do que e como falar), e tal comportamento tinha certamente raízes bem mais profundas do que o mero carreirismo. Era mais provavelmente um mecanismo de defesa, uma repetição do medo e nojo que havia sentido do seu contato com as massas nordestinas de 1952 numa viagem como membro do Teatro do Estudante de Pascoal Carlos Magno: "nunca imaginei que existisse algo igual na face da terra". ${ }^{51} \mathrm{E}$ seria esse nojo diante do Absolutamente Outro, do que não era nem jamais seria "seu" que acabaria por explodir em 1989, às vésperas da eleição presidencial, numa diatribe reacionária em que o aristocratismo simulado esconde muito mal o desespero e o medo:

O que Lula tem com o meu Brasil? Nada. Alguém quer a classe trabalhadora no poder? Bem, não Lênin [sic]. Ler O que fazer? [sic] [...] Lula começou como deveria ter terminado, líder sindical de metalúrgicos, tentando obter melhores condições de trabalho para seus comandados [sic].52 [...] Todos os meus amigos [sic] dizem que o

\footnotetext{
${ }^{50}$ Ver KICISNKI, Bernardo, op. cit., p. 84.

${ }^{51}$ Idem, ibidem, p. 92.

${ }^{52}$ Formulação absurda (desde quando a história é o lugar do dever-ser?) que mostra, no entanto, que mais do que injuriar, o objetivo principal de Francis era o apontado, à época mesmo, por Eduardo Suplicy: "[Francis] procura subestimar a importância do Lula na vida política brasileira e faz isso de maneira consciente". Apud Lord Francis no caldeirão dos nativos. Imprensa, ano III, n. 31, mar. 1990. Disponível em $<$ https://portalimprensa.com.br/imprensa25anos/img/internas/capas/09.pdf >. Acesso em 25 abr. 2021.
} 
país acabou, que não dá mais pé. Acho isso humilhante e mais humilhante ainda ter de escrever sobre essa gente. 53

O texto acima, por sinal, é uma expressão exemplar de uma denegação - Verneinung - freudiana: “o conteúdo de uma imagem ou ideia reprimida pode abrir caminho até a consciência, com a condição de que seja negado". ${ }^{54} \mathrm{~A}$ deformação da concepção leninista (para Lênin, a consciência de classe espontânea não seria uma condição suficiente da ação política socialista do proletariado, mas nem por isso deixa de ser uma condição necessária, sob pena de se romper com a concepção marxista de que "o ser social determina a consciência") serve para que Francis tome abertamente uma posição abjetamente reacionária - pretendendo que tomar tal posição seja "realmente" de esquerda e generalizada (como "todos" dizem...). Ele quer persistir na posição de sujeito discursivo que representa o Outro, negando o fato objetivo de que esse Outro já começou a representar a si mesmo e impõe que se fale dele nos seus próprios termos.

É interessante notar, aliás, que o Francis de 1966 era perfeitamente capaz de desmentir antecipadamente o de 1989, quando escreve que "[Lênin] analisa a dificuldade de os partidos revolucionários se adaptarem às mudanças súbitas da história, quando os slogans certos para ontem tornam-se hoje irremediavelmente arcaicos, embora continuem a ser repetidos com teimosia pelos conservadores inatos". .55

É interessante também perceber que outro intelectual pequeno-burguês ilustrado - não da "classe média" carioca, mas da oligarquia nordestina arruinada - como Gilberto Freyre, ao passar por Columbia e tomar contato com a Antropologia Cultural de Franz Boas - e sua crítica à noção biologizante de raça - na década de 1920, foi capaz de assumir uma posição conservadora que passaria por progressista, ao considerar que a classe dominante brasileira necessitava assumir seu caráter mestiço e sua cultura não ocidental, e reconhecer - paternalisticamente que fosse - as massas populares tal como efetivamente a história pretérita as tinha constituído. Só na sua extrema velhice é que esse programa de realidade revelou-se insuficiente - mas aí ele já tinha idade para ser reacionário sem muito desdouro. Francis voltou da mesma Columbia, nos anos 1950 - onde havia estudado sob a supervisão doutro expatriado, britânico e germanófilo, apetrechado de toda uma série de instrumentos críticos da indústria cultural contemporânea, e com um projeto, ao fim e ao cabo, tão conservador como o freyriano: fazer a cultura brasileira assumir como sua a modernidade, sair do mundo do que ele denominava como do "Nhonhô, a vaca do compadre Ermelindo, e coisas semelhantes" urbana e dotada de uma consciência crítica.

Era, no fundo, algo como o desejo das elites da República Velha, descritas por Freyre em Ordem e progresso, de fazerem tabula rasa do Brasil colonial em prol de um Brasil moderno e "científico" (tudo era científico, até a

\footnotetext{
${ }^{53}$ FRANCIS, Paulo. Diário da Corte, op. cit., p. 332.

${ }^{54}$ FREUD, Sigmund. A denegação. Disponível em <https://psicanalisedownload.files.wordpress.com/2012/08/

dieverneinung1.pdf>. Acesso em 30 dez. 2020.

55 FRANCIS, Paulo. Opinião pessoal, op. cit., p. 28.

56 Idem, ibidem, p. 129.
} 
presidência de Nilo Peçanha...). Só que desta vez o sonho realizou-se: mas de forma tal que devolveu à classe de Francis - a pequeno-burguesia "distinta" que se pretendia forte por força do que Bourdieu chamaria de capital cultural ${ }^{57}$ - a consciência mais que desagradável do seu próprio paternalismo, da "estratificação em camadas" 58 de que ela se julgava isenta. E Francis ainda não tinha envelhecido o suficiente para que sua ultrapassagem intelectual pela história fosse perdoável - nem ele foi capaz de atualizar-se, daí morrer pateticamente abraçado ao seu reacionarismo, tentando desesperadamente manterse relevante à custa de qualquer perfídia.

Francis, na verdade, nunca entendeu bem as consequências últimas da teoria da revolução permanente, que ele interpretava como uma tentativa heroica de ocidentalizar o mundo, de chamar as classes operárias do mundo desenvolvido "em socorro da atrasada Rússia, e [...] estabelecerem o socialismo em escala mundial". ${ }^{59}$ Já escrevi sobre este assunto em outro lugar, mas basta reiterar que, para Trotsky, a teoria da revolução permanente consiste em dizer que as revoluções burguesas são o ontem, que o hoje do liberalismo "exige" objetivamente a revolução socialista.

Historicamente, a expressão política do descontentamento com o capitalismo pode permanecer, dependendo das situações concretas, por longo tempo, num lusco-fusco ideológico - o que Schwarz chama "temário socialista dúbio" 60 - que permite às "classes médias" falarem pelos de baixo, erigir-se em sujeitos de uma razão supraclassista; tal aconteceu tanto nas sociedades da Europa Ocidental - em vários momentos dos séculos XIX e XX - quanto no Brasil dos anos 1960. Há um momento, entretanto, objetivamente inevitável e no Brasil esse momento se deu no início da década de 1980 - em que a materialidade do conflito de classes impõe-se. Como lembrava Trotsky, o marxismo não é uma "cultura", uma análise de textos, senão da luta de classes na sua objetividade.

A modernidade burguesa, em si mesma, contém o atraso, e a superação deste exige o Absolutamente Outro: nas condições brasileiras, o proletariado, mas um proletariado mais que precarizado que tenha a si mesmo por negro e feminino - e isto só para começar. É a "política de identidade" - mas agora sobredeterminada e radicalizada pelas reações de classe subjacentes (é o que explica porque Francis, quanto mais contestado era na sua posição de sujeito do suposto saber, mais odiosamente racista e misógino se tornava). ${ }^{61}$ Tais são os sinais de que a alteridade já está aqui - e muito provavelmente resistirá a qualquer tentativa de repressão e cancelamento.

\section{O que aprender?}

Francis tinha como um dos seus maiores lauréis intelectuais a erudição shakespeareana - mais o fato de haver começado na imprensa com uma crítica

\footnotetext{
${ }^{57}$ BOURDIEU, Pierre. La distinction: critique sociale du jugement. Paris : Minuit, 1979.

${ }^{58}$ FRANCIS, Paulo. Opinião pessoal, op. cit., p. 130.

${ }^{59}$ Idem, Diário da Corte, op. cit., p. 59.

${ }^{60}$ SCHWARZ, Roberto, op. cit. p. 16.

${ }^{61}$ Um exemplo basta: na sua diatribe furiosa anti-PT de 1989, ele solta o comentário odiento: “Lula [...] nos transformaria em Sudão [sic], numa grande bosta". FRANCIS, Paulo. Diário da Corte, op. cit., p. 329.
} 
da adaptação cinematográfica do bardo, o Júlio César, de 1952, dirigido por Joseph L. Mankiewicz ${ }^{62}$ (filme que hoje é conhecido principalmente pela atuação de Marlon Brando como Marco Antônio). Isso permite uma rápida abordagem para a conclusão deste trabalho, por via de uma questão sobre a oportunidade do "enterro" do próprio Francis, já que teria se tornado impossível exaltá-lo - pois the evil that men do lives after them... Mas entre o "exaltar" e o "enterrar", existe um tertium, assinalado por Spinoza: o compreender. Recuperar Paulo Francis, especialmente na sua miséria intelectual final (para dar um sentido mais preciso ao squalor original do conto de Salinger), exige explicá-lo - mais do que ele mesmo, à sua circunstância histórica. É começar pelo mote dado por outro membro da "geração 60 ", o romancista americano Philip Roth, que dizia, ao fim da vida (terminada em misantropia extrema, aliás), ter feito "o melhor que podia com aquilo que tinha".

Podemos resumir - sem nos aprofundarmos muito numa investigação que ultrapassaria os limites atuais deste texto - falando, por exemplo, do contemporâneo mais velho de Francis, Nelson Werneck Sodré, que, num dos seus melhores achados intelectuais como historiador, percebeu que aquilo que ele chamava de revolução brasileira - um processo de radicalização democrática e emancipação nacional - só poderia realizar-se, nas condições históricas legadas pelo passado colonial da sociedade brasileira, a partir de um Sonderweg, uma "revolução passiva" em que incumbiria a uma "classe média atenta e ideologicamente receptiva" ${ }^{63}$ ser o sujeito "substituto" do que seria, objetivamente falando, uma revolução burguesa - e que seria a essa classe que caberia, naquele momento histórico, "ser povo". E, de fato, mesmo depois de 1964, é a classe média letrada que será o sujeito da "democracia" na nossa sociedade. Só que essa pulsão reformista e democrática simplesmente não resistiu - e isso no processo mesmo de redemocratização - à entrada no jogo político do que Trotsky chamava de "as pesadas massas populares". Um caso típico de "o Ser é ele mesmo e outra coisa". E explicar tal dialética, o seu "como", - é explicar, não só Paulo Francis, como boa parte dos seus contemporâneos e muito das causas da nossa história mais recente.

Seja como for, a obra de Francis está aí, e pela luz que ela joga, mesmo que involuntariamente, sobre o nosso ontem, não pode ser simplesmente descartada. Importa apenas que entendamos bem a sua posição no tempo - principalmente, que dela não se poderá tirar a poesia do nosso amanhã.

Artigo recebido em 25 de abril de 2021. Aprovado em 19 de junho de 2021.

\footnotetext{
${ }^{62}$ Idem, ibidem, A segunda mais antiga profissão do mundo, p. 390.

${ }^{63}$ SODRÉ, Nelson Werneck. Raízes históricas do nacionalismo brasileiro. Rio de Janeiro: Iseb, 1960, p. 34.
} 